\title{
A Review and the Length-Weight Relationship of Bluefish, Pomatomus saltatrix (Linnaeus, 1766), Pisces: Pomatomidae, at the Marine Extractive Reserve (RESEX-Mar) of Arraial do Cabo, Rio de Janeiro State, Brazil
}

\author{
Rodrigo Cumplido ${ }^{*}$, Eduardo Barros Fagundes Nettoํㅜ, Marcelo Tardelli Rodrigues1, \\ Ubirajara Gonçalves de Melo Junior'1, Paulo Alberto Silva da Costa ${ }^{2}$ \\ ${ }^{1}$ Programa Associado de Pós-Graduação em Biotecnologia Marinha (PPGBM), Instituto de Estudos do Mar Almirante Paulo \\ Moreira (IEAPM) and Universidade Federal Fluminense (UFF), Arraial do Cabo, Brazil \\ ${ }^{2}$ Departamento de Ecologia e Recursos Marinhos, Laboratório de Dinâmica de Populações Marinhas, Universidade Federal do \\ Estado do Rio de Janeiro (UNIRIO), Rio de Janeiro, Brazil \\ Email: *rodrigo_cumplido@hotmail.com
}

How to cite this paper: Cumplido, R., Netto, E.B.F., Rodrigues, M.T., de Melo Junior, U.G. and da Costa, P.A.S. (2018) A Review and the Length-Weight Relationship of Bluefish, Pomatomus saltatrix (Linnaeus, 1766), Pisces: Pomatomidae, at the Marine Extractive Reserve (RESEX-Mar) of Arraial do Cabo, Rio de Janeiro State, Brazil. Open Access Library Journal, 5: e4770. https://doi.org/10.4236/oalib.1104770

Received: July 11, 2018

Accepted: August 24, 2018

Published: August 27, 2018

Copyright $\odot 2018$ by authors and Open Access Library Inc.

This work is licensed under the Creative Commons Attribution International License (CC BY 4.0).

http://creativecommons.org/licenses/by/4.0/

(c) () Open Access

\begin{abstract}
The bluefish, Pomatomus saltatrix (Linnaeus, 1766), the only representative of the Pomatomidae family, is a key fishing resource that represents a substantial part of the landings at RESEX-Mar of Arraial do Cabo-RJ. The species is broadly distributed throughout the continental shelf in tropical and warm temperate waters of the Atlantic, Pacific and Indian Oceans. It forms pelagic, large and fast moving shoals in relatively deep offshore waters, and draws close to the coast when temperatures reach from $12^{\circ} \mathrm{C}$ to $15^{\circ} \mathrm{C}$. Its displacement is conditioned to the movement of shoals of small fish such as herings; shrimp and squid, all of which are preyed upon. This work had the main purpose of evaluating the growth of bluefish through the distribution of length frequency (One-Way-ANOVA) and the Relationship between Total Length-TL (mm) and Total Weight-TW (g)-LWR; from daily data collections from March/2017 to March/2018. The analyzed specimens were obtained at fish markets of Arraial do Cabo-RJ and fish landings at the Fishermen's Harbor of Praia dos Anjos. They were randomly sampled from fragmented cohorts of the local stock. A total of $\mathrm{N}=2057$ specimens were primary analyzed. TL values varied from $201 \mathrm{~mm}$ (minimum) in February/2018 to $915 \mathrm{~mm}$ (maximum) in September 2017. The average TL was of $541 \mathrm{~mm}$ and the average TW of $1428.5 \mathrm{~g}$. The value of angular coefficient " $\mathrm{b}$ " in the potential flow was 2.6 , and the value of "a" was $9 \mathrm{E}-05$, expressed by the equa-
\end{abstract}


tion $\mathrm{W}=\mathrm{aL}^{\mathrm{b}}$ for overall, where $\mathrm{W}=\mathrm{TW}$ and $\mathrm{L}=\mathrm{TL}$. Values of $\mathrm{W}=3 \mathrm{E}-05 \mathrm{~L}^{2.7}$ were found for females and $\mathrm{W}=2 \mathrm{E}-05 \mathrm{~L}^{2.8}$ for males. Knowledge over their general biology is extremely important when it comes to knowing the ecology of this species for subsidize a future and adequate fishery management.

\section{Subject Areas}

Aquaculture, Fisheries \& Fish Science, Zoology

\section{Keywords}

Bluefish, Fishing Resource, LWR, Subsidize Fishery, Future Management

\section{Introduction}

The bluefish (Pomatomus saltatrix, Linnaeus, 1766) belongs to the order Perciformes and to the Pomatomidae Family [1]-[7]. The species reaches average length of approximately $600 \mathrm{~mm}$, maximum length of approximately $1300 \mathrm{~mm}$, average weight of approximately $3000.0 \mathrm{~g}$ and maximum weight of approximately 14,400.0 g [1] [3] [4] [5] [6] [7]. The bluefish presents different growth ratios between sexes, with females tending to be larger. The length at first maturity varies from $250 \mathrm{~mm}$ to $430 \mathrm{~mm}$ [8]. The maximum age registered is of 14 years [9].

It is a cosmopolitan species that occurs in all tropical and neotropical waters [1] [3] [4] [5] [7] [10], except at the east and northwest of the Pacific Ocean in Figure 1 [6] [7] [10]. In the East Atlantic Ocean (Oriental Atlantic Ocean), it occurs from Portugal to South Africa, including the Mediterranean Sea and the Black Sea, Madeira Island and Canary Islands; in the West Atlantic Ocean (Western Atlantic Ocean), it occurs in the region of Nova Scotia, in Canada and from Bermuda to Argentina; in the Indian Ocean it occurs throughout the east coast of Africa, Madagascar, south of Oman, southeast India, Malay Peninsula and west Australia; and in the Southwest Pacific Ocean it occurs in Australia, except for its northern territory, and in New Zealand in Figure 1 [5] [7] [10]. In Brazil (Southwest Atlantic Ocean), it occurs throughout the entire coastline in Figure 1 [11] [12]; with abundance cycles, sometimes scarce for years and sometimes in incredible quantities that coincide with the abundance cycles of the populations of prey [2]. The space and time analysis of the bluefish distribution in icthyoplankton and of spawning times suggest mainly two stocks in the North Atlantic (Florida Stocks), as well as another in the South Atlantic [13] [14] [15].

In South America, bluefish migrate annually along the coast, northward and seasonally [6]. The species migrates along the coast following the western boundary of the neotropical convergence between the ocean currents of Brazil and Malvinas (Falklands) [16]. Captures suggest seasonal migration upwards: March in Argentina, July in Rio Grande-RS (BR) and November in the state of Santa Catarina (BR) [10]. The bluefish is a migratory pelagic coastal and oceanic 


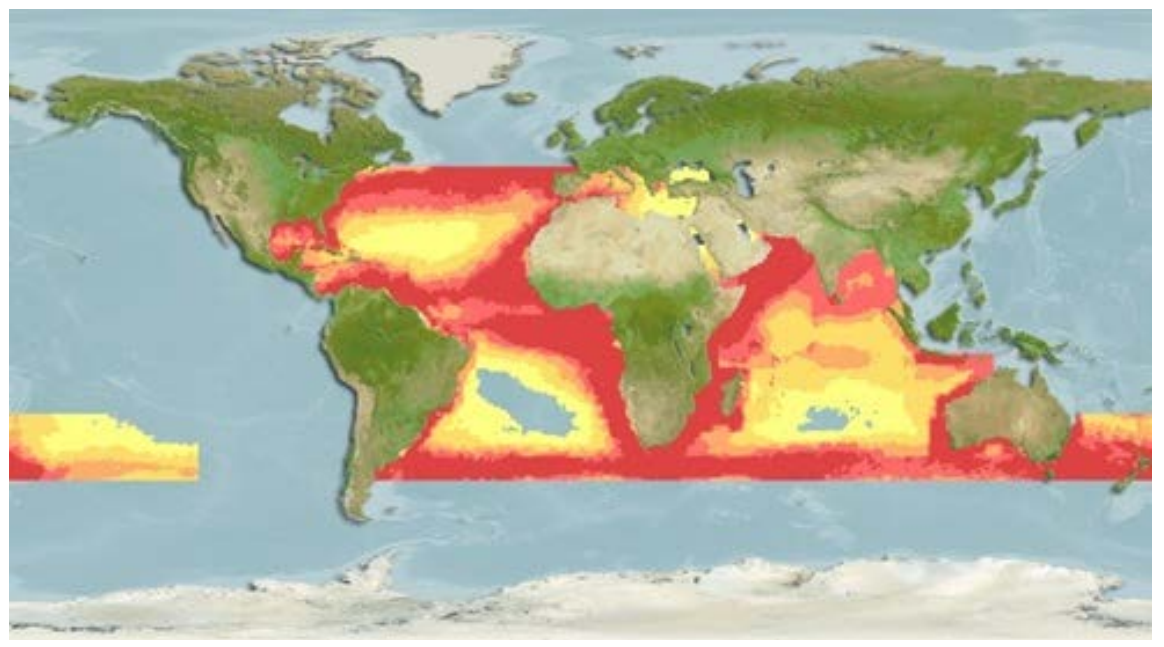

Figure 1. Geographic distribution of Bluefish (Pomatomus saltatrix, Linnaeus 1766). Source: www.aquamaps.org.

species that moves close to the water surface along the continental shelf. Adults migrate to spawning areas, eggs and larvae are usually transported along the coast and the recruits migrate to coastal areas and estuaries where they are mainly piscivorous and grow fast [17]. Bluefish perform apportion egg deposition and have ongoing fertility, generating a great quantity of small eggs during spring migration [18] [19].

It is easily found near shores, especially in surf areas, islands, rocky coasts, agitated areas with foam formation, bays, areas estranged from the coast and around islands. Smaller specimens can also be found in shallow waters of up to 2 $\mathrm{m}$ deeper, estuaries, the young specimens can be found in mangrove forests and lagoons [1]-[7] [10]. Large adult specimens are usually seen by themselves, often associated to billfish and elasmobranchs, while young, with a Total Length (TL) lower than $250 \mathrm{~mm}$, and medium-sized specimens, form small shoals. These shoals can reach up to thousands of individuals [7], and usually draw close to the coast when temperatures reach from $12^{\circ} \mathrm{C}$ to $15^{\circ} \mathrm{C}$ [20].

Bluefish are great swimmers, powerful and voracious predators, the term "saltatrix" means "dancer" in Latin, referring to its great agitation when hooked; who feed off different small and large fish, shellfish such as cephalopods and especially squids, as well as crustaceans, at larvae stage, bluefish feed mainly off copepods [21] [22]. A study conducted in the south of Brazil examined the stomach contents of 516 bluefish specimens [22]. The authors found that, during summer, Pomatomus saltatrix basically fed off four species (Loligo sanpaulensis/Brazilian squid or São Paulo squid, Artemesia longinaris/Argentine shrimp, Mullus argentinae/Argentine goat fish and Paralonchurus brasiliensis/Banded croaker) while, during fall and winter, Pomatomus saltatrix mainly fed off Engraulis anchoita (Argentine anchovy). The authors concluded that the seasonal variation in the diet of the bluefish is related to the availability of prey in the studied area, which confirms the species' opportunist behavior. The search for a dietary pattern over time showed a clearly opportunist characteristic, with no pre- 
ference over prey, and of daytime or crepuscular habit. The presence of organisms along all levels of the water column indicates a demersal-pelagic behavior [23]. There are records of bluefish shoals that kept on attacking and killing even after having satisfied their appetite [5] [6] [7]. Bluefish are capable of eating twice their weight per day. When they attack small fish, bluefish tear them to pieces. There are records of bluefish that regurgitated their food to attack again and also records of a preference for larger prey. Studies show that larger prey excite bluefish in such way that they attack even after being satiate. The bluefish have a compulsion for killing, which makes them a controller of many species' populations, especially of small teleosts from lower trophic levels. When these populations become scarce, bluefish shoals tend to migrate [2].

The reproduction of this species apparently happens in offshore waters, with eggs and pelagic larvae developing while they approach near shore [2], throughout the year, in warmer waters and seems to be seasonal at high latitudes [10]. Despite its larvae capacity for long distance dispersion, the gene flow between the subpopulations is extremely limited [24]. The bluefish has a PLD (Pelagic Larval Duration) oceanic, large and relatively long, which, by the action of the wind and currents, facilitate its global dispersion.

Analysis of the mitochondrial DNA of specimens of Pomatomus saltatrix suggested the existence of an exogenous action in the Atlantic Ocean that, due to environmental influence, generates many morphotypes [25]. A recent study indicated that the populations in both Western and Eastern Atlantic Ocean seem to be isolated [25].

In the South Atlantic of the USA, spawning happens from March to May, September to November and May to August [27]. Spring and summer spawning, generate neonates that migrate from the estuaries to the continental platform of the USA during the beginning of fall, while adults are found at the continental platform during summer and fall [28]. Spawning in the Gulf of Mexico may occur in April and from April to November [29]; larvae are rare in the west of the Gulf. In the Brazilian coast, spring spawning probably happens in the south, near the Rio Grande-RS (BR) coast, at Parcel dos Carpinteiros. According to the methods of analysis used and quoted by [10], the Gonadosomatic Index (GSI) of captured males at Rio Grande-RS (BR) shows a higher value in November, while the Gonadosomatic Index (GSI) of females is high from October to March, with peaks in November and March, indicating apportioned egg deposition. Spawning, seasonal migration and life cycle are strongly linked to temperature. Spawning occurs in superficial waters with temperatures varying from $20^{\circ} \mathrm{C}$ to $26.8^{\circ} \mathrm{C}[17]$.

The bluefish, in Figure 2; is an important fishing resource all over the world, representing a large share of all fish landings of Arraial do Cabo-RJ. Its fishing activity is intense, using purse seines, dragging nets, hand lines, gill nets and many others [30].

Currently, fishing continues to be the main source of impact on marine and coastal environments, contributing to the global loss of biodiversity [31] [32] 


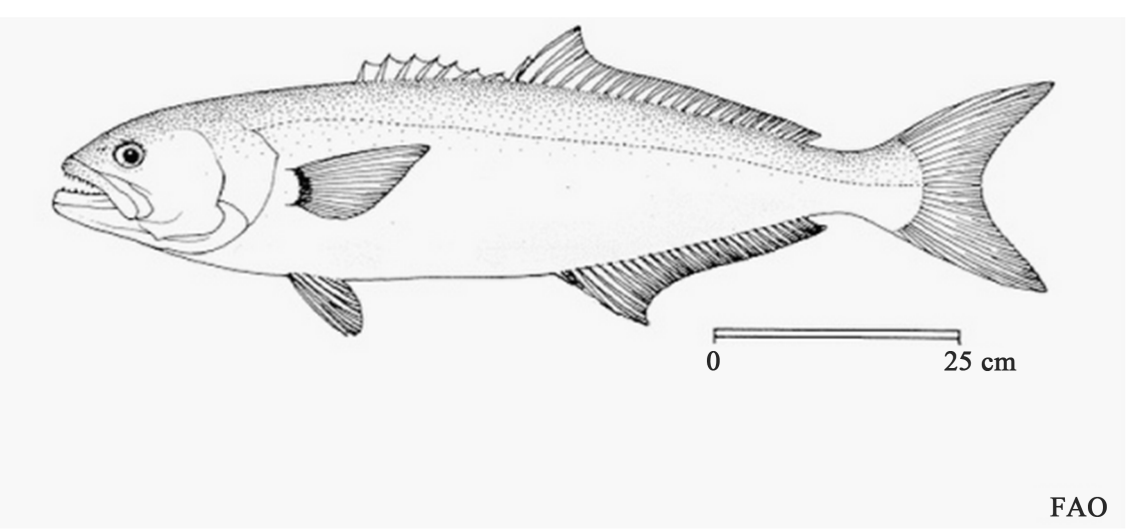

Figure 2. Left-flank view of the Bluefish (Pomatomus saltatrix, Linnaeus, 1766). Source: www.fishbase.org.

[33] [34]. In the Southwest Atlantic Ocean, the patterns of marine resource exploitation are similar to those reported all over the world [33] [34] [35] [36], with generalized population decreases and collapsed stocks [34] [37] [38] [39]. The history of production in Brazil shows different levels over time, with the tendency to downfall. During the 70 's, production was around 16 thousand tons, while in the 80 's it went down to 8 thousand tons. For the last two decades, it has been stable around 4 thousand tons, a clear index of over exploitation. In the beginning of the 70 's, fishing was $400 \%$ higher. The state of Rio de Janeiro is known for keeping a constant production since the 90's, annually producing around 1 thousand ton [10]. It is estimated that $23 \%$ of all marine fishery stocks in Brazil are being totally exploited and 33\% are being over exploited, including species of lower trophic levels [40] [41] [42].

The bluefish is framed into the category of over exploited living resources, those that, from such a high level of capture of specimens of all ages, show a reduction lower than safe levels in biomass, potential to spawn and future captures [43]. A management plan must be developed, aiming to recovery the stock and the sustainability of the species' fishing [43]. Brazilian Normative Instruction MMA N.53/2005 currently establishes, among other species of fish, a minimum of $350 \mathrm{~mm}$ size for captured Pomatomus saltatrix, specimens with possible first spawning already performed and possible matures, as long as there is no use of gill nets or part in amateur fishing competitions. This norm has a poor regional validity and extends through the coast of the states of Espírito Santo (BR); Rio de Janeiro (BR) with fishing tackle or prohibition not yet attributed; São Paulo (BR); Paraná (BR); Santa Catarina (BR) and Rio Grande do Sul (BR) [10].

Size variation has important implications on many aspects of fisheries science and population dynamics [44]. Studies on Length-Weight Relationship (LWR) are very limited [45]-[50]. The study of LWRs is considered important to obtain different types of information such as growth rates, age structures, age at first maturity, stock discrimination and studies on population dynamics [50]-[58] to subsidize futures and betters fisheries managements around the world. Other than that, LWRs can also be used to find the relative condition factor, establish- 
ing performance equations to estimate the number of fish landings and compare the population in space and time [59]. LWRs are usually calculated through linear regression of data transformed into logarithms. According to the literature, the Ordinary Least Square Method (OLS), or "predictive" regression [60], is the most commonly applied method to estimate LWR's parameters. Parameter "b" of the LWR equation $\left(\mathrm{W}=\mathrm{a} \mathrm{L}^{\mathrm{b}}\right)$, where $\mathrm{W}=$ Total Weight $(\mathrm{TW})$ and $\mathrm{L}=$ Total Length (TL), also known as the isometry coefficient, has an important biological meaning, indicating the rate of weight increase related to length increase. Variability in the value of " $b$ " is usually detected among different populations of the same species or within the same population at different times. This may be a reflection of changes in conditions related to feeding, reproduction or migratory activities of individuals [61] [62]. The maximum length and weight are important parameters used to study life histories and fisheries science. Therefore, it is important to regularly update the maximum size of commercially relevant species [63].

The idea of creating the Arraial do Cabo Marine Extractive Reserve (RESEXMar), a Conservation Unit (UCs or CUs) for sustainable use, emerged as a comeback to the industrial fishing fleets that come from big cities and have been invading the seas of Arraial do Cabo since the 80's [64] [65], conducting fishing activities in areas used by local artisanal fishermen. It was the first Marine Extractive Reserve in Brazil, created by a Presidential Decree in January 3, 1997 [66]. The establishment of a National System of Conservation Units (SNUC) by Law N. 9.985/2000 caused some changes in the definition of extractive reserve in Decree $98.897 / 90$, which described it as a territory purposed for autosustainable exploitation of natural resources by extractive populations, managed by Chico Mendes Institute of Biodiversity Conservation (ICMBio), created by Federal Law 11,516 of August 28, 2007. In these terms, the RESEX-Mar becomes a co-managed instrument of natural resources and marine ecosystems, for it distributes the power of decision among the State and the communities of people who use these resources [67].

Currently, the city of Arraial do Cabo, may be considered as one of the most traditional fisheries nuclei in the Rio de Janeiro State, due to its production indexes [68]. According to national statistics, these indexes place Arraial do Cabo-RJ among the cities with the greatest fishery productions in the country [69]. This kind of pressure may lead to the depletion and abandonment of the management model agreed upon in local cultures [67].

The main purpose of this work is evaluating the growth of bluefish through the distribution of length frequency (One-way-ANOVA) to provide information on the Length-Weight Relationships (LWRs) of bluefish (Pomatomus saltatrix, Linnaeus, 1766) a key captured fishing resource that represents a substantial part of the landings at RESEX-Mar, coast of Arraial do Cabo-RJ. And through daily collection, of data from commercial captures bought, for a year, reveal possible changes undergone by the species during its growth throughout the months (season annual distribution). Considering that the region is an important 
RESEX-Mar, a Conservation Unit for sustainable use, it also has the purpose of summarize information on fishing activities and captures of the species to the community. These data will be presented to the local agencies in order to subsidize a future and better fisheries management of the studied area. And, if possible, the model of the present study can be applied to other conservation units around the world; since, currently, there are few related studies.

\section{Materials and Methods}

\subsection{Studied Area}

Located on the east coast of Rio de Janeiro State, the region of Arraial do Cabo (Lat. $23^{\circ} \mathrm{S}$ - Long. $42^{\circ} \mathrm{W}$ ), in Figure 3; presents favorable conditions for fishing activities.

The region has an important characteristic: a unique ocean projection in comparison to the coast, which makes it one of the locations in the Brazilian coast that most advances towards the sea. The geographical aspect is determinant to an upwelling's situation system, that brings up cold waters rich in nutrients from the South Atlantic Central Water (SACW/ACAS), with peaks during spring and summer [70] [71].

The Arraial do Cabo-RJ RESEX-Mar has a marine range of three miles off the coast toward the ocean and 56,769 hectares of water line, according to approximate geographic coordinates: Western Limit: Southern Boundary-22 $56{ }^{\prime} 21^{\prime \prime}-$
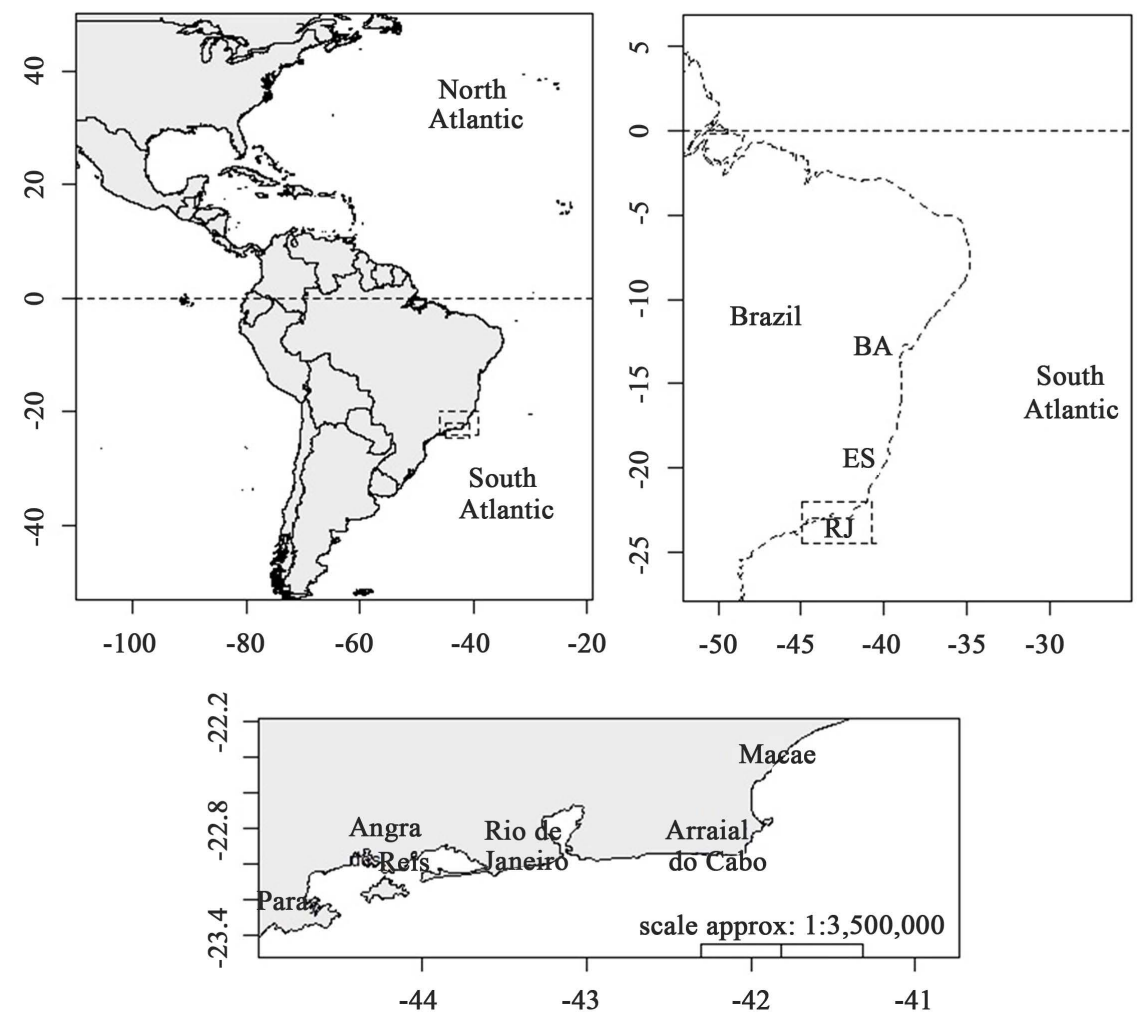

Figure 3. The Brazilian coast, with the location of Arraial do Cabo (Lat. $23^{\circ} \mathrm{S}$ - Long. $42^{\circ} \mathrm{W}$ ), located on the east coast of the Rio de Janeiro State, southeast of Brazil. 
Eastern Boundary- $042^{\circ} 18^{\prime} 02^{\prime \prime}$; Northwestern Limit: Southern Boundary$22^{\circ} 56^{\prime} 00^{\prime \prime}$ - Eastern Boundary-041 ${ }^{\circ} 55^{\prime} 30^{\prime \prime}$; Southern Limit: Southern Boundary

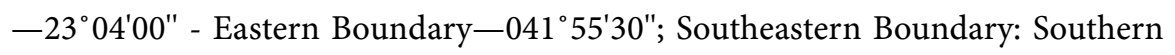

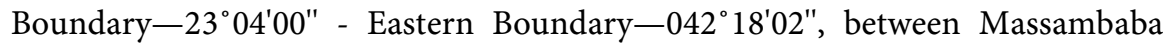
Beach, at Pernambuca, and Pontal Beach, at the border of Cabo Frio [67] in Figure 4.

\subsection{Samplings}

The samples were collected daily between March/2017 and March/2018 from fish markets of Arraial do Cabo-RJ, fish landings at the Fishermen's Harbor at Praia dos Anjos (RESEX-Mar) and also from data conceived by the Fishing Institute Foundation of Arraial do Cabo (FIPAC). The specimens, visually identified only by their external morphology, were captured in different ways such as hand lines, long lines, dragging nets, gillnets and beach nets. They were randomly sampled from fragmented cohorts of the local stock according to monthly production and the availability of copies for sale; so that there was an integral comprehension of the different size classes from the catches originated by the different fishing efforts. For procedures, a primary biometry, of fresh specimens,

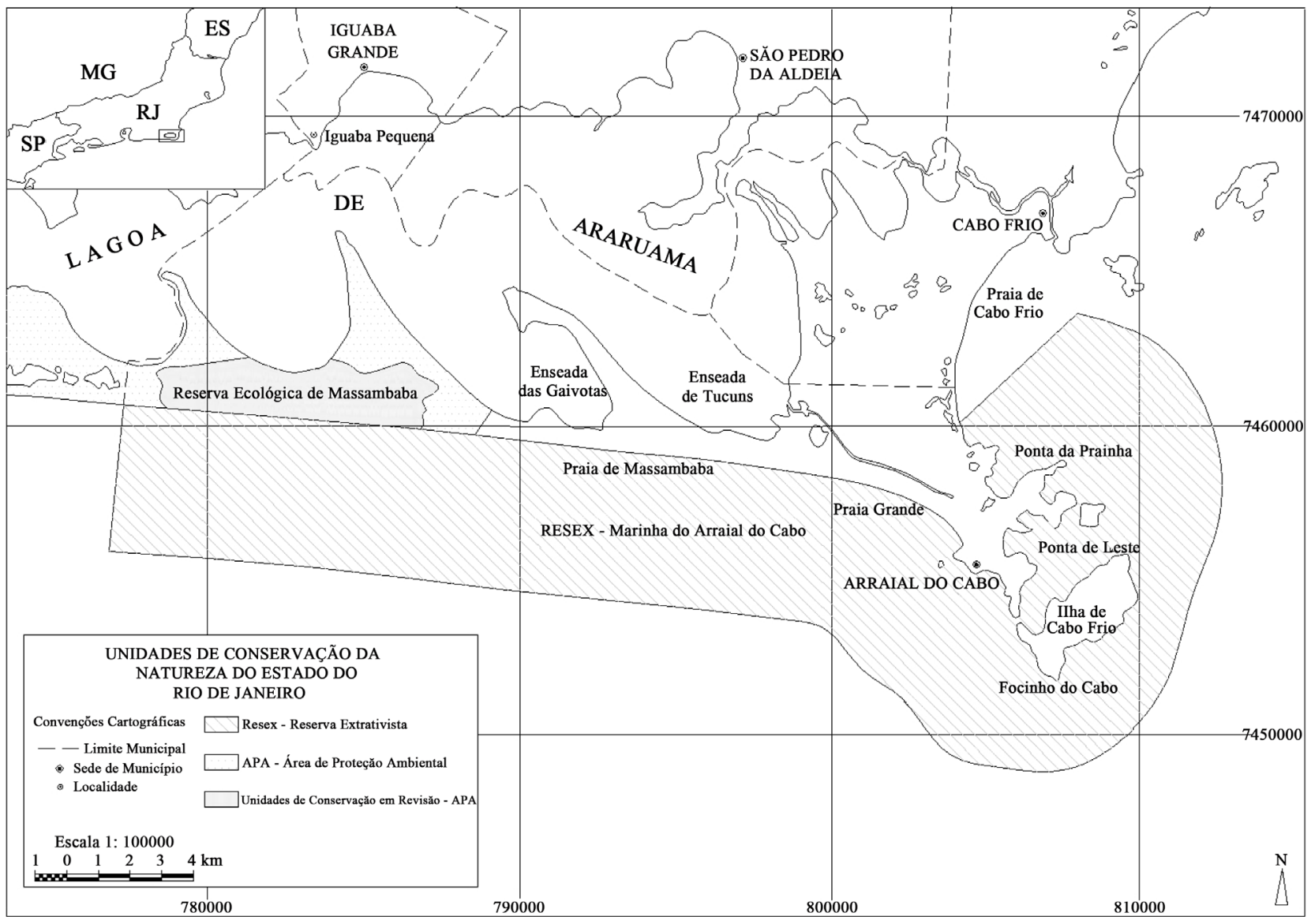

Figure 4. Map of Arraial do Cabo-RJ Marine Extractive Reserve (RESEX-Mar). Source: Adapted from the Nature Conservation Units Atlas, Government of Rio de Janeiro State/SEMA, 2001. 
was carried out in loco. For dissection, a posteriori, samples bought were taken to the laboratory as quickly as possible and then frozen. Fish had their Total Length (TL) determined in millimeters $(\mathrm{mm})$, from the initial end (mouth) to the final end (end of the caudal fin), starting from zero, with their left flank facing up, on the graduated ruler; and their Total Weight (TW) determined in grams (g) on the electronic balance, Marte AC10k model.

\subsection{Analysis}

The estimated values of LWRs were calculated using the equation $\mathrm{W}=\mathrm{aL}^{\mathrm{b}}[72]$. This may be shown in a linear regression way after the logarithmic transformation through $\log \mathrm{W}=\log (\mathrm{a})+\mathrm{b} \log (\mathrm{L})$, where $\mathrm{W}$ represents the Total Weight-TW (g), and L the Total Length-TL $(\mathrm{mm})$, " $a$ " is the intercept and " $\mathrm{b}$ " is the parameter of the inclination growth curve. The null hypothesis of Isometric Growth $(\mathrm{HO} b=3)$ were assumed. If inclinations (b) were significantly different from 3, for growth types will indicate Allometric Positive $(b>3)$ or Allometric Negative $(b<3)$ [73]. The value of " $b$ " is considered as a regularly distributed logarithm [74] and reflects the species's morphology [75]. For sex determination, only the classification according to the macroscopic visual analysis of the gonads was performed. The Analysis of Variance ANOVA (One-Way) and Tukey test were employed to evaluate if there was differences among the samples between the months. The degree of association (correlation) between variables was calculated through the $\mathrm{R}^{2}$ determination coefficient ( 0 to 1 ). All of the statistical analyses were confronted by the level or significance of $\mathrm{p} \leq 0.05$.

The descriptive statistics derived from the use of statistic functions of MICROSOFT EXCEL ${ }^{\circledR} 2007$ and of STATISTICA ${ }^{\mathrm{TM}}$.

\section{Results}

In total, $\mathrm{N}=2057$ bluefish were collected and, among them, $\mathrm{N}=202$ were bought and dissected. Females $(\mathrm{N}=109 / 53.9 \%)$ slightly prevailed over Males (N $=59 / 29.2 \%$ ), being $1.84 / 1$ the sex ratio proportion; and over samples of Unsexed specimens $(\mathrm{N}=34 / 16.8 \%)$. The term "Unsexed" refers to those specimens, to which the authors were unable to identify the sex, from the macroscopic visual analysis of the gonads only, since they are extremely filamentous, thus hindering their sexual differentiation. According to the results, there was low statistically meaningful differences between months in terms of length and weight ( $\mathrm{p} \leq$ 0.05), with Females tending to be larger between sexes. Minimum and maximum bluefish's Total Length (TL) varied between $201 \mathrm{~mm}$, in February/2018, and 915 $\mathrm{mm}$, in September/ 2017, respectively. The average TL was of $541 \mathrm{~mm}$ and the average Total Weight (TW) of $1428.5 \mathrm{~g}$.

The LWRs showed high association (correlation) between length and weight of bluefish, all confronted by the level or significance of $\mathrm{p} \leq 0.05$. The values of $\mathrm{R}^{2}$ (0 to 1) for Females, Males, Unsexed specimens and for Overall were, defined as $0.990 ; 0.988 ; 0.981$ and 0.932 , respectively. The LWRs, for Females, Males, 
Unsexed specimens and for Overall were defined as $\mathrm{W}=3 \mathrm{E}-05 \mathrm{~L}^{2.7} ; \mathrm{W}=$ $2 \mathrm{E}-05 \mathrm{~L}^{2.8} ; \mathrm{W}=6 \mathrm{E}-05 \mathrm{~L}^{2.6}$ and $\mathrm{W}=9 \mathrm{E}-05 \mathrm{~L}^{2.6}$, respectively in Figure 5 . The LWR's parameters of fish are affected by the external environment, degree of stomach fullness, maturity of the gonads, diet, sex, etc. In the present study, we especially reference the general upwelling's peaks influence [76] [77] [78].

The LWR's "b" parameters usually vary from 2.0 to 3.5 [79]. In the present study, the estimated growth coefficient (b), for Females, Males, Unsexed specimens and for Overall, were within the references expected interval of $2.50-3.33$ (they were: Females " $b$ " $=2.781$, (deviation $(\mathrm{HO} b=3)=0.219)$; Males " $b$ " = 2.844, (deviation $(\mathrm{HO} b=3)=0.156)$; Unsexed specimens " $\mathrm{b}$ " $=2.657$, (deviation $(\mathrm{HO} b=3)=0.343)$ and Overall " $b "=2.617$, (deviation $(\mathrm{HO} b=3)=0.383)$, all showed low deviation. According to the results of the present study and according to the references compared, the type of growth of the bluefish were Allometric Negative $(b<3)$, for Females, Unsexed specimens and for Overall. For Males, the type of growth was considered Isometric $(b=3$, or next) in Figure 5.

In the present study, the results of the averages for TL and for TW, for overall fishes, showed that the month of May (autumn) of 2017 and the month of February (summer) of 2018 presented the highest $(627 \mathrm{~mm}$ and $2061.3 \mathrm{~g}$ ) and the lowest (435 $\mathrm{mm}$ and $822.6 \mathrm{~g}$ ), respectively. For the separated sexes, bought and dissected specimens, the highest averages (556 $\mathrm{mm}$ and $1569.2 \mathrm{~g}$ ) were in June (winter) of 2017 and the lowest averages (274 $\mathrm{mm}$ and $289.5 \mathrm{~g}$ ) were also in February (summer) of 2018.
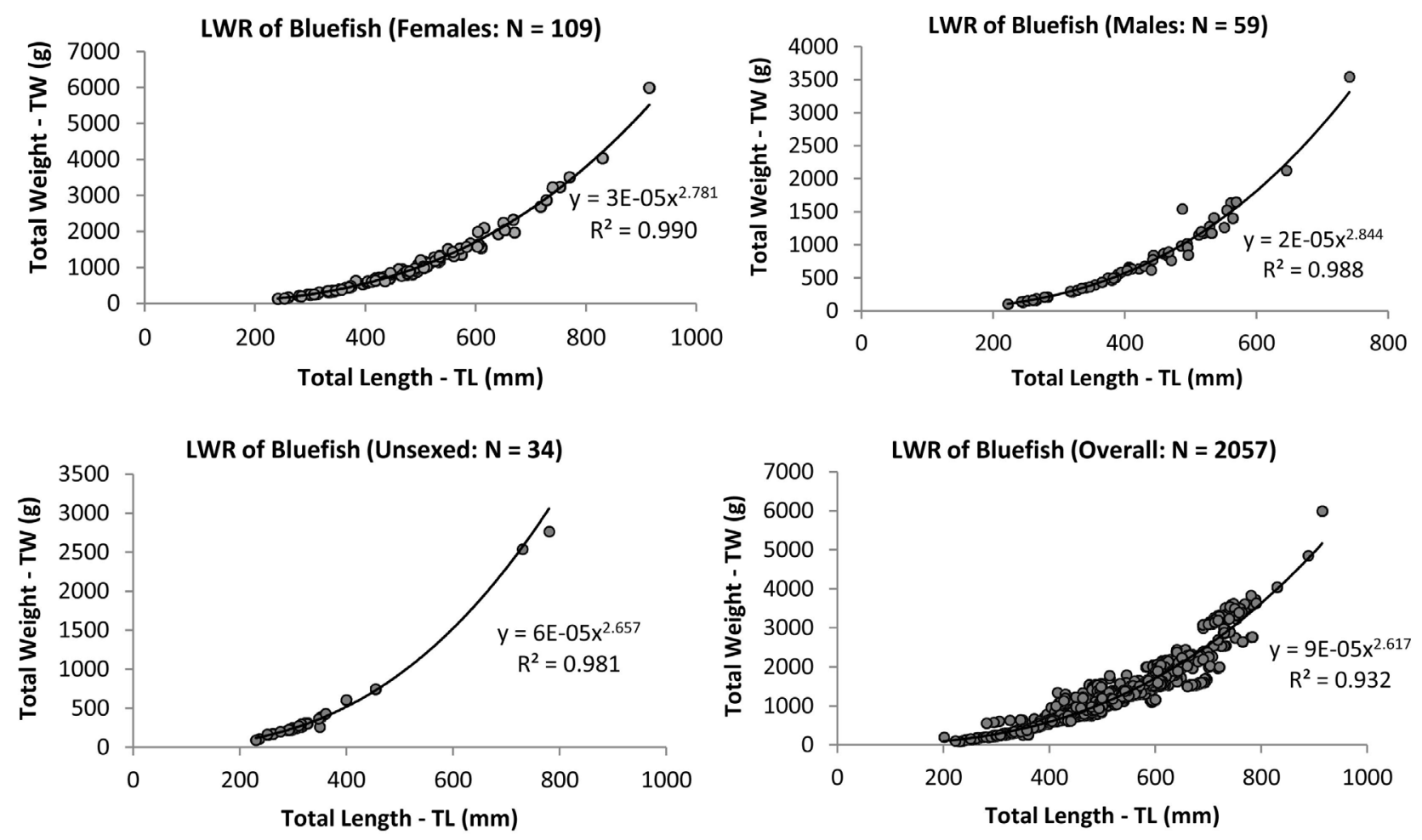

Figure 5. The general Length-Weight Relationships (LWRs/p $\leq 0.05$ ) of the Bluefish, Pomatomus saltatrix (Linnaeus, 1766), Pisces: Pomatomidae, from the area of Arraial do Cabo-RJ RESEX-Mar, Brazil. 
The distributions of TL Classes $(\mathrm{mm})$ for the bluefish, in the present study, mostly presented a normal growth curve, corroborating with the description of the references and with being expected in Figure 6.

The monthly distribution of TL Classes $(\mathrm{mm})$ for the separated sex, according to production and the availability of copies for sale, presented smaller difference and standard deviation among the means as expected in Figure 7, probably, caused by the lower number of samples $(\mathrm{N})$.

For Overall, the monthly distribution of TL Classes (mm), according to the analysis below (One-way-ANOVA) employed to evaluate if there were differences among the monthly samples, with the Tukey test presenting $\mathrm{F}=94.6$ and $\mathrm{p}=0.0$ $(\mathrm{p} \leq 0.05)$ and with the result of Kruskal-Wallis test (KW) of 822.5; $\mathrm{p}=0.0$ ( $\mathrm{p} \leq$ 0.05 ), showed a low difference between the averages of the growth rates between the months sampled thus presenting low standard deviation too in Figure 8.

\section{Discussion}

Studies demonstrate that most fish do not change their body shapes as adults [75]. Very strong deviations of $b=3$ usually result from questionable studies [74] [75]. The Length-Weight Relationship parameters are extremely important for the biology of fish and their fisheries management [80]. The Le Cren's concept hypothetically affirms that the ideal "b" value for fish is 3 , indicating an Isometric Growth that is broadly used as a scale in the study of LWRs [81]. Different " $b$ " values refer to fishing periods, abiotics ecological factors, food provision, spawning conditions, etc. The type of growth of the species may change
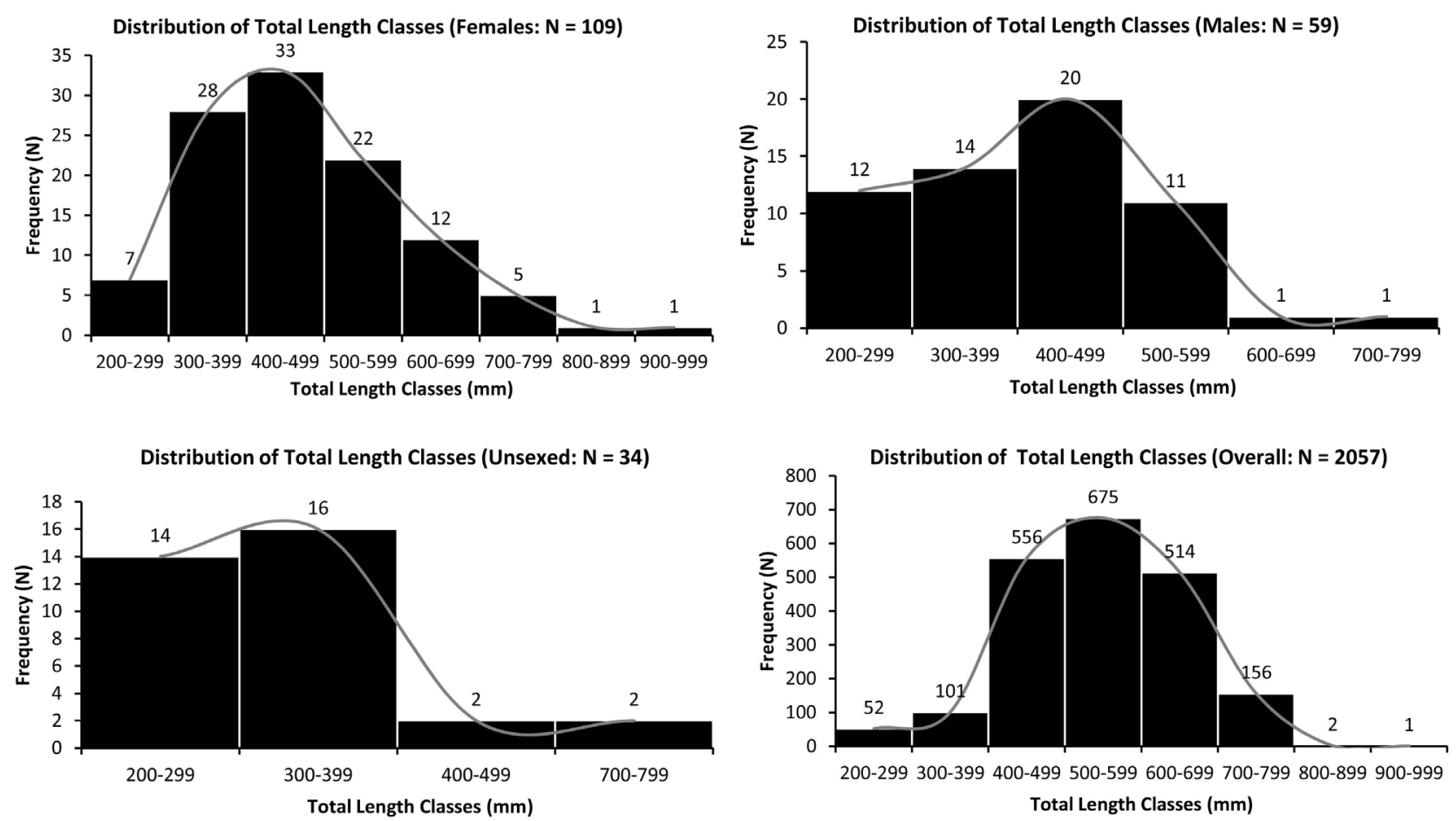

Figure 6. The general Distribution of Total Length Classes (mm) of the Bluefish, Pomatomus saltatrix (Linnaeus, 1766), Pisces: Pomatomidae, from the area of Arraial do Cabo-RJ RESEX-Mar, Brazil. 


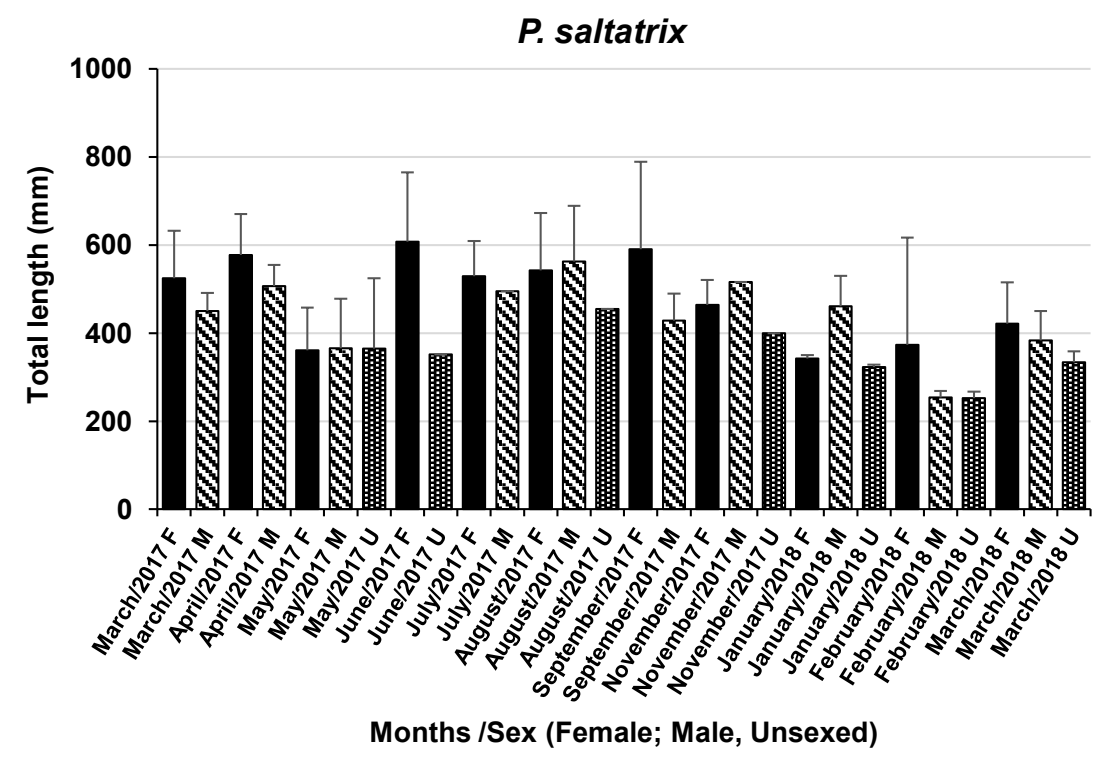

Figure 7. The monthly distribution of Total Length Classes $(\mathrm{mm})$ for the separated sex of Bluefish, Pomatomus saltatrix (Linnaeus, 1766), Pisces: Pomatomidae, from the area of Arraial do Cabo-RJ RESEX-Mar, Brazil.

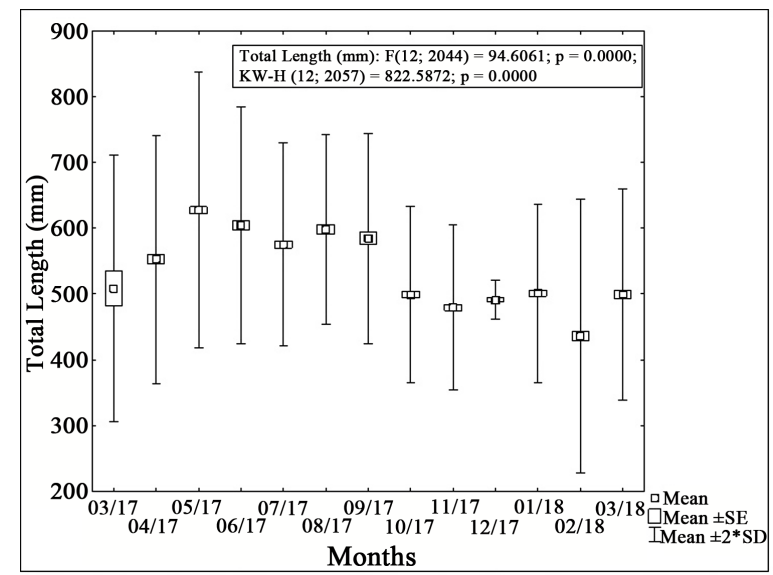

Tukey HSD test for Total Length $(\mathrm{mm}) .\left({ }^{*} p<0.05\right)$

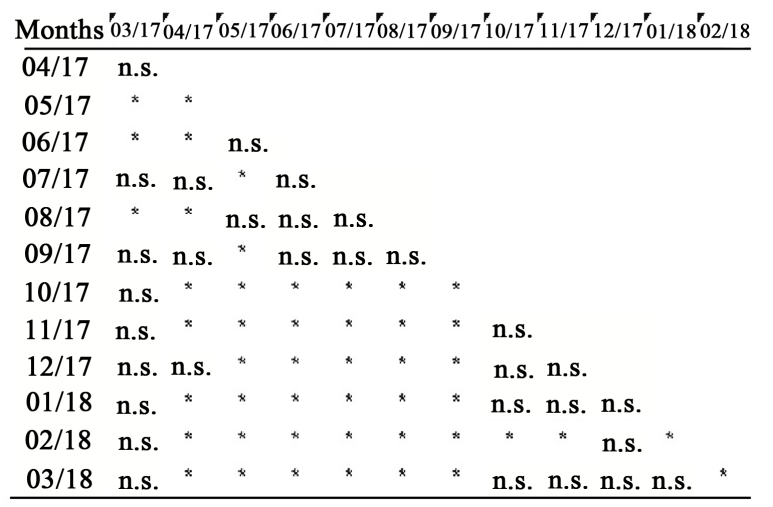

Figure 8. One-way-ANOVA: Mean values, standard deviation and significance analysis (Tukey's test, Kruskal-Wallis Test and p's) of the Total Length values (mm) for Bluefish, Pomatomus saltatrix (Linnaeus, 1766), Pisces: Pomatomidae, from the area of Arraial do Cabo-RJ RESEX-Mar, Brazil. 
among locals. Intra-specific variations in the Length-Weight Relationships might happen due to variations in ecological conditions of habitats, in physiology or in any of those [59]. Other than that, these differences depend on time and size of the sample, greatest amplitude, on the non-selective fishing equipment, on seasonality, fishing pressure, reproductive season, etc.

When comparing LWRs available in the literature, one can find and extensive variability of parameters for this species in Figure 9. Variables related to sampling include the size of the sample, the distribution of length, the type of length measurement, while nutritional conditions represent the intrinsic biological variability [82].

It is known that individuals in populations that are exposed to high levels of mortality and/or fishing pressure will respond by reproducing in medium size and lower ages [83]; with the LWR's Relationship growths parameter " $b$ " tending to present Allometric Negative $(b<3)$ or Allometric Positive $(b>3)$. Parameter " $b$ " of the LWR equation $\left(\mathrm{W}=\mathrm{aL}^{\mathrm{b}}\right)$, where $\mathrm{W}=$ Total Weight $(\mathrm{TW})$ and $\mathrm{L}$ $=$ Total Length (TL), also known as the isometry coefficient, has an important biological meaning, indicating the rate of weight increase related to length increase. Variability in the value of "b" is usually detected among different populations of the same species or within the same population at different times. This may be a reflection of changes in conditions related to feeding, reproduction or migratory activities of individuals [61] [62].

The pattern for bluefish captures through the years has shown significant reductions in the local stock. During the 60 's, great captures were averaged in

\begin{tabular}{|c|c|c|c|c|c|c|c|c|}
\hline References & Location & $\mathrm{N}$ (sample size) & Sex & Length range (mm) & Length Type & a (Parameter of LWR) & b (Parameter of LWR) & Growth Type \\
\hline [88] & South Atlantic & - & Overall & - & $\mathrm{TL}$ & 0.010 & 2.770 & A- \\
\hline [89] & Middle Black Sea & - & Overall & - & $\mathrm{TL}$ & 0.038 & 2.560 & A- \\
\hline [90] & South Coast of Brazil & 92 & Overall & $240.0-480.0$ & $\mathrm{TL}$ & $6.00 \mathrm{E}-06$ & 3.050 & I \\
\hline [91] & South Coast of Brazil & 275 & Overall & $86.0-250.0$ & $\mathrm{TL}$ & $6.79 \mathrm{E}-06$ & 3.050 & I \\
\hline [92] & Atlantic & - & Overall & $86.0-910.0$ & $\mathrm{TL}$ & 0.091 & 3.010 & I \\
\hline [45] & Middle Coast of Brazil & 67 & Overall & $480.0-755.0$ & - & 0.059 & 2.500 & A- \\
\hline [93] & Aegean \& Marmara Sea & 2817 & Overall & $84.0-453.0$ & FL & 0.006 & 3.220 & - \\
\hline \multirow[t]{3}{*}{ [46] } & Middle Black Sea & 76 & Females & $143.0-217.0$ & $\mathrm{TL}$ & 0.011 & 2.920 & I \\
\hline & & 67 & Males & $132.0-217.0$ & $\mathrm{TL}$ & 0.015 & 2.790 & $\mathrm{~A}-$ \\
\hline & & 143 & Overall & $132.0-217.0$ & $\mathrm{TL}$ & 0.013 & 2.860 & A- \\
\hline [48] & Middle Black Sea & 820 & Overall & $92.0-234.0$ & $\mathrm{TL}$ & 0.003 & 3.320 & - \\
\hline [47] & Eastern Black Sea & 14 & Overall & $116.0-222.0$ & $\mathrm{TL}$ & 0.003 & 3.330 & $\mathrm{~A}+$ \\
\hline [94] & North Marmara Sea & 290 & Overall & $106.0-240.0$ & TL & 0.032 & 2.520 & A- \\
\hline [23] & Black Sea & 25 & Overall & $125.0-202.0$ & $\mathrm{TL}$ & 0.009 & 3.000 & - \\
\hline \multirow[t]{4}{*}{ [49] } & South Marmara Sea & 503 & Females & $131.0-370.0$ & $\mathrm{TL}$ & 0.010 & 2.960 & I \\
\hline & & 447 & Males & $123.0-473.0$ & $\mathrm{TL}$ & 0.010 & 2.970 & I \\
\hline & & 280 & Unsexed & $130.0-316.0$ & $\mathrm{TL}$ & 0.015 & 2.830 & I \\
\hline & & 1230 & Overall & $123.0-473.0$ & $\mathrm{TL}$ & 0.010 & 2.950 & I \\
\hline [50] & Middle Black Sea & - & Overall & $135.0-236.0$ & $\mathrm{TL}$ & 0.008 & 3.120 & $A+$ \\
\hline \multirow[t]{4}{*}{ The Present Study } & Southeast Coast of Brazil & 109 & Females & $241.0-915.0$ & $\mathrm{TL}$ & $3.00 \mathrm{E}-05$ & 2.781 & $A-$ \\
\hline & & 59 & Males & $222.0-741.0$ & $\mathrm{TL}$ & $2.00 \mathrm{E}-05$ & 2.844 & I \\
\hline & & 34 & Unsexed & $230.0-780.0$ & $\mathrm{TL}$ & $6.00 \mathrm{E}-05$ & 2.657 & $\mathrm{~A}-^{-}$ \\
\hline & & 2057 & Overall & $201.0-915.0$ & $\mathrm{TL}$ & $9.00 \mathrm{E}-05$ & 2.617 & A- \\
\hline
\end{tabular}

I: Isometric; A+: Positive allometric and A-: Negative allometric.

Figure 9. Extra Compiled: A table of the Length-Weight Relationships (LWRs) of Bluefish, Pomatomus saltatrix (Linnaeus, 1766), from different studies, years and locations; including the present study. 
$18,000 \mathrm{~kg}$. From the 80 's on, production started to decrease. Nowadays, around $370 \mathrm{~kg}$ of bluefish per day is considered great. Studies show that, in fifty years (1960 to 2010), the quantity of captured bluefish in a good day has decreased in approximately 70\%. A study showed that the Capture per Unit Effort (CPUE) varied from 14.2 tons per hour in 1996 to 0.3 ton per hour in 2004, with a yearly average of 4 tons per hour [34]. According to data provided by FIPAC, the total monthly capture of bluefish, resulting from the productive sum between all fishing efforts, from January/2017 to February/2018, varied from 8559 to 14,326 $\mathrm{kg}$, presenting the lowest capture of $2361 \mathrm{~kg}$ in September/2017 and the highest, corresponding to 14,326 kg, in February/2018. In Arraial do Cabo, impacts on marine ecosystems have affected the environmental base lines of three consecutive generations [34]. The captivity of bluefish showed signs of excessive effort and a possible excessive fishing.

The bluefish is considered as Vulnerable (VU $A 2 b d$ ), due to data uncertainty, but there is no regulation or national listing to guarantee its protection [84] [85] [86]. In this case, the monitoring of Arraial do Cabo-RJ RESEX-Mar should have a more precautionary function [67]. Measures for conservation, suggested by many, include the reduction of fishing efforts by purse seines and a capture limit for juveniles [87]; the official determination of a closure season, of 4 monthsDecember 1 to March 31, during the summer-autumn spawning and upwelling's peaks, as well as the establishment of a minimum capture size of $350 \mathrm{~mm}$, specimens with possible first spawning already performed and possible matures, probably avoiding the capture of recruits; reinforcing that the Rio de Janeiro State (BR) is without fishing tackle or prohibition yet attributed [10].

Studies suggest a need for improved monitoring of all fisheries, including often neglected small-scale fisheries, and illegal and other problematic fisheries, as well as discarded by-catch [95]. The low attention that small-scale fisheries endure in most parts of the world [95] [96] manifests itself in potentially misleading statistics that are submitted annually by member countries of the Food and Agriculture Organization of the United Nations (FAO), which may exclude or substantially underreport small-scale fisheries data [95] [97].

The most important trend of the world marine fisheries catches is not one of "stability" as carefully suggested earlier by FAO, but one of decline [95]. Until now artisanal and subsistence fisheries generate about one-third to one-half of the total global catch, as assessed by catch reconstructions for all maritime countries of the world [95] [96] [97].

For the monthly analysis of Overall, there was a greater difference between the means of TL ( $\mathrm{mm}$ ) and a greater standard deviation, since for the monthly analysis between separated sexes a smaller difference and a smaller standard deviation were found, probably caused by the lower number of samples $(\mathrm{N})$. However, it can be observed that there is significant difference between the TL Classes (mm) monthly. Any standard deviation, more pronounced, is possibly caused by the entry of new recruits throughout the year (season annual distribution). 
The statistical test used was the Analysis of Variance-ANOVA (One-Way). It is a parametric test used to verify if there are differences between the means of a given variable (response variable. Ex.: TL Classes $(\mathrm{mm})$ ) in relation to a treatment with two or more categorical levels (predictor variable. Ex.: Months). The Tukey test for mean comparison was applied when the " $F$ " test was significant (at the present study, Tukey test presenting $\mathrm{F}=94.6$ and $\mathrm{p}=0.0(\mathrm{p} \leq 0.05)$ ). The Kruskal-Wallis test (KW) was also applied (results at the present study: $822.5 ; \mathrm{p}$ $=0.0(\mathrm{p} \leq 0.05))$. It is a nonparametric test used to compare three or more categorical levels. It is used to test the null hypothesis that all categorical levels have equal distribution functions against the alternative hypothesis that at least two of the categorical levels have different distribution functions, has no restriction on the comparison. The degree of association (correlation) between variables was calculated through the $\mathrm{R}^{2}$ determination coefficient ( 0 to 1 ), and all showed high association (correlation) with $\mathrm{R}>0.9$. All of the statistical analyses were confronted by the level or significance of $\mathrm{p} \leq 0.05$.

\section{Conclusions}

The present study, with the great feedback of the local fishermen, have identified the months of November and December (spring and summer) of 2017; January, February and March (summer and summer-autumn) of 2017 and 2018 as the reproductive peaks of larger adult individuals (spawning peaks) and the month of March (summer-autumn) of 2017 and February (summer) of 2018 as the most productive, periods coinciding with the peaks of the local upwelling. It was observed that in 2017 the bluefish was the sixth most captured species in the studied area. Is a remarkable fishing resource around the world, accounting for approximately $12.7 \%$ (200 T/year) of all fish landed in the region of Arraial do Cabo-RJ.

For effects of a better future fisheries management, it would be necessary calculate and establish lower exploitation levels in reason of inaccuracies calculations in Maximum Sustainable Yield (MSY), obtained when the instantaneous fishing mortality rate is approximately equal to the natural mortality rate. Where values and the abiotic variables in the processes of reproduction and growth, still not well known.

The explored stock in the region may be formed by one single cohort that, during its period of growth, changes local and spawning season or apportioned, or of many different subpopulations.

The present study should be used to compare the data obtained with other studies that were carried out in different times and places. Results can be used by biologists as a reference during researches of local fisheries. Other than that, it is very important to provide recent data for dynamic analysis of populations, locals stocks and others.

The knowledge over bluefish biology is extremely important to the ecology and conservation status of this species. 
Considering that the region is an important RESEX-Mar for sustainable use, collected more information on fishing activities and captures of the species are real necessary. Providing these data to local agencies in order to subsidize a future and better fisheries management of the studied area and, if possible, to other conservation units around the world, since there are few related studies, is fundamental.

\section{Acknowledgements}

We thanks the PPGBM-IEAPM/UFF for the study opportunity; IEAPM for the structure; FIPAC for the data provided; the workers of Arraial do Cabo-RJ fish markets, especially Alexandre ("Peixaria do Sardinha"), for the samples; our good friends from the Program; general secretary Jorge (IEAPM) for all the help; fisherman "Mito" and the CNPq for the conceded scholarship.

\section{Conflicts of Interest}

The authors declare no conflicts of interest regarding the publication of this paper.

\section{References}

[1] Figueiredo, J.L. and Menezes, N.A. (1980) Manual de Peixes Marinhos do Sudeste do Brasil, III-Teleostei (2). University of São Paulo (USP), Museum of Zoology of the University of São Paulo, Editora da Universidade de São Paulo (Edusp), São Paulo, 90 p.

[2] Carvalho-Filho, A. (1994) Peixes costa brasileira. Editora Marca D’água, São Paulo, $308 \mathrm{p}$.

[3] Szpilman, M. (2000) Peixes marinhos do Brasil-Guia prático de identificação. Instituto Ecológico Aqualung (IEA), Donnelley-Cochrane Gráfica Editora do Brasil Ltda., Rio de Janeiro, 288 p.

[4] Figueiredo, J.L., Santos, A.P., Yamaguti, N., Bernardes, R.A. and Rossi-Wongtschowski, C.L.D.B. (2002) Peixes da Zona Econômica Exclusiva da Região SudesteSul do Brasil-Levantamento com rede de meia água. University of São Paulo (USP), Editora da Universidade de São Paulo (Edusp), São Paulo, 242 p.

[5] Bernardes, R.A., Figueiredo, J.L., Rodrigues, A.R., Fischer, L.G., Vooren, C.M., Haimovici, M. and Rossi-Wongtschowski, C.L.D.B. (2005) Peixes da Zona Econômica Exclusiva da Região Sudeste-Sul do Brasil-Levantamento com armadilhas, pargueiras e rede de arrasto de fundo. University of São Paulo (USP), Editora da Universidade de São Paulo (Edusp), São Paulo, 304 p.

[6] Hostim-Silva, M., Andrade, A.B., Machado, L.F., Gerhardinger, L.C., Daros, F.A., Barreiros, J.P. and Godoy, E. (2006) Peixes de Costão Rochoso de Santa Catarina, IArvoredo. University of Vale do Itajaí (UNIVALI), Editora da Universidade do Vale do Itajaí (UNIVALI), Itajaí, 148 p.

[7] FISHBASE. Catalog of All Fish species Known to Science. (2013). http://www.fishbase.org/home.htm

[8] Krug, L.C. and Haimovici, M. (1989) Idade e Crescimento da Enchova Pomatomus saltatrix do Sul do Brasil. FURG-DO. Editora Atlântica, Rio Grande-RS, 11, 47-61.

[9] Sipe, A.M. and Chittenden Jr., M.E. (2002) A Comparison of Calcified Structures 
for Ageing Bluefish in the Chesapeake Bay Region. Transactions of the American Fisheries Society, 131, 783-790. https://doi.org/10.1577/1548-8659(2002)131<0783:ACOCSF>2.0.CO;2

[10] CEPSUL. Centro de Pesquisa e Gestão dos Recursos Pesqueiros do Litoral Sudeste e Sul (2009) Relatório sobre a reunião técnica para o ordenamento da pesca de anchova (Pomatomus saltatrix) nas regiões sudeste e sul do Brasil. Itajaí, 98 p.

[11] Lucena, F.M., O’Brien, C.M. and Reis, E.G. (2002) Effects of Exploitation by Two Co-Existing Fleets on the Bluefish, Pomatomus saltatrix, in Southern Brazil: An Application of a Seasonal Catch-at-Age Model. Marine and Freshwater Research, 53, 835-847. https://doi.org/10.1071/MF00093

[12] Lucena, F.M. and O'Brien, C.M. (2005) The Consequences of Different Scenarios in the Management of the Gillnet and Purse-Seine Fisheries Targeting Pomatomus saltatrix and Cynoscion guatucupa in Southern Brazil: A Bio-Economic Approach. Journal of Marine Science, 62, 201-213.

[13] Norcross, J.J., Richardson, S.L., Massmann, W.H. and Joseph, E.B. (1974) Development of Young Bluefish (Pomatomus saltatrix) and Distribution of Eggs and Young in Virginian Coastal Waters. Transactions of the American Fisheries Society, 103, 477-497. https://doi.org/10.1577/1548-8659(1974)103<477:DOYBPS>2.0.CO;2

[14] Kendall, A.W. and Walford, L.A. (1979) Sources and Distribution of Bluefish, Pomatomus saltatrix, Larvae and Juveniles off the East Coast of the United States. Fishery Bulletin US, 77, 213-227.

[15] Collins, M.R. and Stender, B.W. (1987) Larval King Mackeral (Scomberomorus cavalla) Spanish Mackeral, (S. maculatus) and Bluefish (Pomatomus saltatrix) off the Southeast Coast of the United State, 1973-1980s. Bulletin of Marine Science, 41, 822-834.

[16] Haimovici, M. and Krug, L.C. (1996) Life History and Fishery of the Enchova, Pomatomus saltatrix, in Southern Brazil. Marine and Freshwater Research, 47, 357-363. https://doi.org/10.1071/MF9960357

[17] Juanes, F., Hare, J.A. and Miskiewicz, A.G. (1996) Comparing Early Life History Strategies of Pomatomus saltatrix: A Global Approach. Marine and Freshwater Research, 47, 365-379. https://doi.org/10.1071/MF9960365

[18] Salekhova, L.P. (1959) On the Development of the Bluefish (Pomatomus saltatrix). Proceedings of Sevastopol Biological Station, 11, 182-188.

[19] Deuel, D.G., Clark, J.R. and Mansueti, A.J. (1966) Description of Embryonic and Early Larval Stages of Bluefish Pomatomus saltatrix. Transactions of the American Fisheries Society, 95, 264-271. https://doi.org/10.1577/1548-8659(1966)95[264:DOEAEL]2.0.CO;2

[20] Richards, S.W. (1976) Age, Growth, and Food of Bluefish (Pomatomus saltatrix) from East-Central Long Island Sound from July through November 1975. Transactions of the American Fisheries Society, 105, 523-525. https://doi.org/10.1577/1548-8659(1976)105<523:AGAFOB >2.0.CO;2

[21] Marks, R.E. and Conover, D.O. (1993) Ontogenetic Shift in the Diet of Young-ofYear Bluefish Pomatomus saltatrix during the Oceanic Phase of the Early Life History. Fishery Bulletin, 91, 97-106.

[22] Lucena, F.M., Vaske Jr., T., Ellis, J.R. and O’Brien, C.M. (2000) Seasonal Variation in the Diets of Bluefish, Pomatomus saltatrix (Pomatomidae) and Striped Weakfish, Cynoscion guatucupa (Sciaenidae) in Southern Brazil: Implications of Food Partitioning. Environmental Biology of Fishes, 57, 423-434.

https://doi.org/10.1023/A:1007604424423 
[23] Kasapoğlu, N. and Düzgüneş, E. (2013) Length-Weight Relationships of Marine Species Caught by Five Gears from the Black Sea. Mediterranean Marine Science, 15, 95-100. https://doi.org/10.12681/mms.463

[24] Goodbred, C.O. and Graves, J.E. (1996) Genetic Relationships among Geographically Isolated Populations of Bluefish (Pomatomus saltatrix). Marine and Freshwater Research, 47, 347-355. https://doi.org/10.1071/MF9960347

[25] Graves, J.E., McDowell, J.R., Beardsley, A.M. and Scoles, D.R. (1992) Stock Structure of the Bluefish Pomatomus saltatrix along the Mid-Atlantic Coast. Fishery Bulletin, 90, 703-710.

[26] Pardiñas, A.F., Campo, D., Pola, I.G., Miralles, L., Juanes, F. and Garcia-Vazquez, E. (2010) Climate Change and Oceanic Barriers: Genetic Differentiation in Pomatomus saltatrix (Pisces: Pomatomidae) in the North Atlantic Ocean and the Mediterranean Sea. Journal of Fish Biology, 77, 1993-1998. https://doi.org/10.1111/j.1095-8649.2010.02774.x

[27] Hare, J.A. and Cowen, R.K. (1993) Expatriation of Xyrichtys novacula (Pisces: Labridae) Larvae: Evidence of Rapid Cross Slope Exchange. Journal of Marine Resources, 49, 801-823. https://doi.org/10.1357/002224091784995675

[28] Buckel, J.A., Fogarty, M.J. and Conover, D.O. (1998) Foraging Habits of Bluefish, Pomatomus saltatrix, on the U.S. East Coast Continental Shelf. Fisheries Bulletin, 97, 758-775.

[29] Ditty, J.G. and Shaw, R.F. (1995) Seasonal Occurrence, Distribution, and Abundance of Larval Bluefish, Pomatomus saltatrix (Family: Pomatomidae), in the Northern Gulf of Mexico. Bulletin of Marine Science, 56, 592-601.

[30] Cengiz, Ö. (2014) A New Maximum Length Record of the Bluefish (Pomatomus saltatrix Linnaeus, 1766) for Turkey Seas. BEU Journal of Science, 3, 113-116.

[31] Roberts, C., Hawkins, J.P. and Campaign, W.E.S. (2000) Fully-Protected Marine Reserves: A Guide. WWF Endangered Seas Campaign, Washington DC.

[32] Dulvy, N., Polunin, N.V., Mill, A. and Graham, N.A. (2004) Size Structural Change in Lightly Exploited Coral Reef Fish Communities: Evidence for Weak Indirect Effects. Canadian Journal of Fisheries and Aquatic Sciences, 61, 466-475. https://doi.org/10.1139/f03-169

[33] Jackson, J.B. (2008) Ecological Extinction and Evolution in the Brave New Ocean. Proceedings of the National Academy of Sciences, 105, 11458-11465. https://doi.org/10.1073/pnas.0802812105

[34] Bender, M.G., Machado, G.R., Silva, P.J.A., Floeter, S.R., Monteiro-Netto, C., et al. (2014) Local Ecological Knowledge and Scientific Data Reveal Overexploitation by Multigear Artisanal Fisheries in the Southwestern Atlantic. PLOS ONE, 9, e110332. https://doi.org/10.1371/journal.pone.0110332

[35] Myers, R.A. and Worm, B. (2003) Rapid Worldwide Depletion of Predatory Fish Communities. Nature, 423, 280-283. https://doi.org/10.1038/nature01610

[36] Halpern, B.S., Walbridge, S., Selkoe, K.A., Kappel, C.V., Micheli, F., et al. (2008) A Global Map of Human Impact on Marine Ecosystems. Science, 319, 948-952. https://doi.org/10.1126/science.1149345

[37] Floeter, S., Halpern, B.S. and Ferreira, C. (2006) Effects of Fishing and Protection on Brazilian Reef Fishes. Biological Conservation, 128, 391-402. https://doi.org/10.1016/j.biocon.2005.10.005

[38] Fredou, T. (2004) The Fishing Activity on Coral Reefs and Adjacent Ecosystems: A Case Study of the Northeast of Brazil. Cybium, 28, 274. 
[39] Rezende, Sd.M. and Ferreira, B.P. (2004) Age, Growth and Mortality of Dog Snapper Lutjanus jocu (Bloch \& Schneider, 1801) in the Northeast Coast of Brazil. Brazilian Journal of Oceanography, 52, 107-121. https://doi.org/10.1590/S1679-87592004000200003

[40] Pauly, D., Christensen, V., Dalsgaard, J., Froese, R. and Torres, F. (1998) Fishing down Marine Food Webs. Science, 279, 860-863. https://doi.org/10.1126/science.279.5352.860

[41] Ferreira, C. and Gonçalves, J. (1999) The Unique Abrolhos Reef Formation (Brazil), Need for Specific Management Strategies. Coral Reefs, 18, 352-352. https://doi.org/10.1007/s003380050211

[42] Freire, K.M. and Pauly, D. (2010) Fishing down Brazilian Marine Food Webs, with Emphasis on the East Brazil Large Marine Ecosystem. Fisheries Research, 105, 57-62. https://doi.org/10.1016/j.fishres.2010.02.008

[43] Ministério do Meio Ambiente (2004) Diário Oficial da União-Seção 1. 136-142.

[44] Erzini, K. (1994) An Empirical Study of Variability in Length at Age of Marine Fishes. Journal of Applied Ichthyology, 10, 17-41. https://doi.org/10.1111/j.1439-0426.1994.tb00140.x

[45] Frota, L.O., Costa, P.A.S. and Braga, A.C. (2004) Length-Weight Relationships of Marine Fishes from the Central Brazilian Coast. World Fish Center Quarterly, 27, 20-26.

[46] Kalayc1, F., Samsun, N., Bilgin, S. and Samsun, O. (2007) Length-Weight Relationship of 10 Fish Species Caught by Bottom Trawl and Midwater Trawl from the Middle Black Sea, Turkey. Turkish Journal of Fisheries and Aquatic Sciences, 7, 33-36.

[47] Ak, O., Kutlu, S. and Aydın, İ. (2009) Length-Weight Relationship for 16 Fish Species from the Eastern Black Sea. Turkish Journal of Fisheries and Aquatic Sciences, 9, 125-126.

[48] Özdemir, S., Erdem, Y., Özdemir Birinci, Z. and Erdem, E. (2009) Karadenizde dip trolü ile Ekim ve Kasim aylarinda avlanan lüfer (Pomatomus saltatrix, L.) baliğinin av verimi ve boy kompozisyonun karşilaştirilmasi. Erciyes, Üniversitesi Fen Bilimleri Enstitüsü Dergisi, 25, 400-408.

[49] Bal, H., Yanık, T. and Türker, T. (2015) Length-Weight and Length-Length Relationships of the Bluefish Pomatomus saltatrix (Linnaeus. 1766) Population in the South Marmara Sea of Turkey. Alinteri, 29, 26-33.

[50] Özpiçak, M., Saygın, S. and Polat, N. (2017) The Length-Weight and Length-Length Relationships of Bluefish, Pomatomus saltatrix (Linnaeus, 1766) from Samsun, Middle Black Sea Region. NE Sciences, 2, 28-36. https://doi.org/10.28978/nesciences.349265

[51] Kohler, N., Casey, J. and Turner, P. (1995) Length-Weight Relationship for 13 Species of Sharks from the Western North Atlantic. Fishery Bulletin, 93, 412-418.

[52] Stergiou, K. and Politou, C.Y. (1995) Biological Parameters, Body Length-Weight and Length-Height Relationships for Various Species in Greek Waters. Naga, 18, 42-45.

[53] Morey, G., Moranta, J., Massut, E., Grau, A., Linde, M., Riera, F. and Morales-Nin, B. (2003) Weight-Length Relationships of Littoral to Lower Slope Fishes from the Western Mediterranean. Fisheries Research, 62, 89-96. https://doi.org/10.1016/S0165-7836(02)00250-3

[54] Sinovcic, G., Franicevic, M., Zorica, B. and Ciles-Kec, V. (2004) Length-Weight and Length-Length Relationships for 10 Pelagic Fish Species from the Adriatic Sea 
(Croatia). Journal of Applied Ichthyology, 20, 156-158. https://doi.org/10.1046/j.1439-0426.2003.00519.x

[55] Vaslet, A., Bouchon-Navaro, Y., Louis, M. and Bouchon, C. (2008) Weight-Length Relationships for 20 Fish Species Collected in the Mangroves of Guadeloupe (Lesser Antilles). Journal of Applied Ichthyology, 24, 99-100. https://doi.org/10.1111/j.1439-0426.2007.01023.x

[56] Borah, S., Bhattacharjya, B.K., Saud, B.J., Yadav, A.K., Debnath, D., Yengkokpam, S., Das, P., Sharma, N., Singh, N.S. and Sarma, K.K. (2017) Length-Weight Relationship of Six Indigenous Fish Species from Deep or Beel, a Ramsar Site in Assam, India. Journal of Applied Ichthyology, 33, 655-657.

https://doi.org/10.1111/jai.13348

[57] Ergüden, D., Ergüden, S.A., Özdemir, O. and Gürlek, M. (2017) Length-Weight Relationship and Condition Factor of Spotted Flounder Citharus linguatula (Linnaeus, 1758) in Iskenderun Bay, North-Eastern Mediterranean, Turkey. NESciences, 2, 11-17.

[58] da Silva, V.E.L., Teixeira, E.C., Batista, V.S. and Fabré, N.N. (2017) Length-Weight Relationships of Two Mugilids Species from Tropical Estuarine Systems in Alagoas, Northeastern Coast of Brazil. Journal of Applied Ichthyology, 33, 631-632. https://doi.org/10.1111/jai.13325

[59] Le Cren, E.D. (1951) The Length-Weight Relationship and Seasonal Cycle in Gonad Weight and Conditions in the Perch (Perca fluviatilis). Freshwater Biology Association, 20, 201-219. https://doi.org/10.2307/1540

[60] Zar, J.H. (1984) Biostatistical Analysis. Prentice Hall, Upper Saddle River.

[61] King, M. (1995) Fisheries Biology, Assessment and Management. Fishing New Books, Blackwell Science Ltd., Cambridge.

[62] Froese, R. (2006) Cube Law, Condition Factor, and Weight-Length Relationships: History, Meta-Analysis and Recommendations. Journal of Applied Ichthyology, 22, 241-253. https://doi.org/10.1111/j.1439-0426.2006.00805.x

[63] Navarro, M.R., Villamor, B., Myklevoll, S., Gil, J., Abaunza, P. and Canoura, J. (2012) Maximum Size of Atlantic Mackerel (Scomber scombrus) and Atlantic Chub Mackerel (Scomber colias) in the Northeast Atlantic. Cybium, 36, 406-408.

[64] Pimenta, E. and Hargreaves, P. (1999) Relatório de avaliação técnica da viabilidade de zoneamento costeiro e oceânico para bioprodução e atividades complementares. IBAMA-Cabo Frio and COPPE/UFRJ.

[65] Seixas, C.S. (2008) Co-Managing a Complex Commons: The Case of a Marine Protected Area Established along a Coastal Urban Setting in Brazil. 12 th Biennial Conference of the International Association for the Study of Commons, 1-21.

[66] Kruel, V.S. da F. and Peixoto, A.L. (2004) Etnobotânica na Reserva Extrativista Marinha de Arraial do Cabo, RJ, Brazil. Acta Botanica Brasilica, 18, 177-190. https://doi.org/10.1590/S0102-33062004000100015

[67] Moraes, E.A., et al. (2008) A leitura da Gestão Socioambiental da Reserva Extrativista Marinha de Arraial do Cabo sob a Ótica dos Pescadores Locais (III Relatório Técnico). Laboratório de Sistemas Avançados de Gestão da Produção do Programa de Engenharia de Produção da Universidade Federal do Rio de Janeiro (UFRJ). $1-20$.

[68] Azevedo Silva, P.J. (2004) Onze Anos de Produção Pesqueira na Região de Arraial do Cabo RJ. Niterói: MS.c. Dissertation, Department of Marine Biology UFF.

[69] Secretaria Especial de Aqüicultura e Pesca/Instituto Brasileiro do Meio Ambiente e 
dos Recursos Naturais Renováveis-SEAP/IBAMA (2005) Normative Instruction SEAP No. 6 de 04/05/2005.

[70] Valentin, J.L. (1994) A ressurgência-fonte de vida dos oceanos. Ciência Hoje, 18, 18-25.

[71] Rodrigues, M.T. (2011) Ressurgência-fenômeno da vida. Revista do Meio Ambiente, 5, 22-23.

[72] Ricker, W.E. (1979) Growth Rates and Models. In: Hoar, W.S., Randal, D.J. and Brett Jr., Eds., Fish Physiology Vol. VIII. Bioenergetics and Growth, Academic Press, Cambridge, 677-743. https://doi.org/10.1016/S1546-5098(08)60034-5

[73] Sokal, R.R. and Rholf, F.J. (1987) Introduction to Biostatistics. Freeman and Co., New York, 365s.

[74] Carlander, K.D. (1977) Handbook of Freshwater Fishery Biology, Vol. 2. The Iowa State University Press, Ames, 431.

[75] Froese, R., Thorson, J.T. and Reyes, R.B. (2014) A Bayesian Approach for Estimating Length-Weight Relationships in Fishes. Journal of Applied Ichthyology, 30, 78-85. https://doi.org/10.1111/jai.12299

[76] Tesch, W. (1971) Growth Rates and Models. In: Ricker, W.E., Ed., Methods for Assessment of Fish Production in Fresh Waters, 2nd Edition, International Biological Program, Oxford and Edinburg, 97-130.

[77] Bagenal, T.B. and Tesch, F.W. (1978) Age and Growth. In: Bagenal, T., Ed., Methods for Assessment of Fish Production in Fresh Waters, 3rd Edition, IBP Handbook No. 3, Blackwell Science Publications, Oxford.

[78] Hossain, M.Y., Ahmed, Z.F., Leunda, P.M., Toksanul İslam, A.K.M., Jasmine, S., Oscoz, J., Miranda, R. and Ohtomi, J. (2006) Length-Weight and Length-Length Relationships of Some Small Indigenous Fish Species from the Mathabhanga River, South-Western Bangladesh. Journal of Applied Ichthyology, 22, 301-303. https://doi.org/10.1111/j.1439-0426.2006.00801.x

[79] Froese, R. and Pauly, D. (2010) Fishbase: World Wide Web Electronic Publication. http://www.fishbase.org/search.php

[80] Garcia, C.B., Buarte, J.O., Sandoval, N., Von Schiller, D. and Mello, N.P. (1989) Length-Weight Relationships of Demersal Fishes from the Gulf of Salamanca, Colombia. Fishbyte, 21, 30-32.

[81] Singh, M. and Serajuddin, M. (2017) Length-Weight, Length-Length Relationship and Condition Factor of Channa punctatus Collected from Three Different Rivers of India. Journal of Entomology and Zoology Studies, 5, 191-197.

[82] Ricker, W.E. (1975) Computation and Interpretation of Biological Statistics of Fish Populations. Bulletin of the Fisheries Research Board of Canada 191.

[83] Helfman, G.S., Collatte, B.B., Facey, D.E. and Bowen, B.W. (2009) The Diversity of Fishes: Biology, Evolution and Ecology. 2nd Edition, Wiley-Blackwell, Hoboken, 720 s.

[84] Carpenter, K.E., Ralph, G., Pina Amargos, F., Collette, B.B., Singh-Renton, S., Aiken, K.A., Dooley, J. and Marechal, J. (2015) Pomatomus saltatrix. The IUCN Red List of Threatened Species 2015: e.T190279A115314064. http://dx.doi.org/10.2305/IUCN.UK.2015-4.RLTS.T190279A19929357.en

[85] Bender, M., Floeter, S., Mayer, F., Vila-Nova, D., Longo, G., et al. (2013) Biological Attributes and Major Threats as Predictors of the Vulnerability of Species: A Case Study with Brazilian Reef Fishes. Oryx, 47, 259-265.

https://doi.org/10.1017/S003060531100144X 
[86] FAO (2011) Fishstat-FAO Fishery and Aquaculture Global Statistics. http://www.fao.org/fishery/statistics/software/fishstatj/en

[87] Silvano, R. and Begossi, A. (2010) What Can Be Learned from Fishers? An Integrated Survey of Fishers' Local Ecological Knowledge and Bluefish (Pomatomus saltatrix) Biology on the Brazilian Coast. Hydrobiologia, 637, 3-18. https://doi.org/10.1007/s10750-009-9979-2

[88] Barger, L.E. (1990) Age and Growth of Bluefish Pomatomus saltatrix from the Northern Gulf of Mexico and U.S. South Atlantic Coast. Fishery Bulletin, 88, 805-809.

[89] Erkoyuncu, İ., Erdem, M., Samsun, O., Özdamar, E. and Kaya, Y. (1994) A Research on the Determination of Meat Yields. Chemical Composition and Weight-Length Relationship of Some Fish Species Caught in the Black Sea. Istanbul University Journal of Aquatic Products, 8, 181-191.

[90] Bernardes, R.A. and Rossi-Wongtschowski, C.L.D.B. (2000) Length-Weight Relationship of Small Pelagic Fish Species of the Southeast and South Brazilian Exclusive Economic Zone. NAGA, 23, 30-32.

[91] Haimovici, M. and Velasco, G. (2000) Length-Weight Relationship of Marine Fishes Southern Brazil. NAGA, 23, 19-23.

[92] Morato, T., Afonso, P., Loirinho, P., Barreiros, J.P., Santos, R.S. and Nash, R.D.M. (2001) Length-Weight Relationships for 21 Costal Fish Species of the Azores. North-Eastern Atlantic. Fisheries Research, 50, 297-302. https://doi.org/10.1016/S0165-7836(00)00215-0

[93] Ceyhan, T. (2005) Bluefish in the North Aegean and Marmara Region (Pomatomus saltatrix L. 1766) Some Characteristics of Population Studies. Ege University, Institute of Science and Technology.

[94] Bok, T.D., Göktürk, D., Kahraman, A.E., Alicli, T.Z., Acun, T., et al. (2011) Length-Weight Relationships of 34 Fish Species from the Sea of Marmara, Turkey. Journal of Animal and Veterinary Advances, 10, 3037-3042.

[95] Pauly, D. and Zeller, D. (2016) Catch Reconstructions Reveal That Global Marine Fisheries Catches Are Higher than Reported and Declining. Nature Communications, 7, Article No. 10244. https://doi.org/10.1038/ncomms10244

[96] Pauly, D. (2006) Major Trends in Small-Scale Marine Fisheries, with Emphasis on Developing Countries, and Some Implications for the Social Sciences. Marit. Studies, 4, 7-22.

[97] Zeller, D., Harper, S., Zylich, K. and Pauly, D. (2015) Synthesis of Under-Reported Small-Scale Fisheries Catch in Pacific-Island Waters. Coral Reefs, 34, 25-39. https://doi.org/10.1007/s00338-014-1219-1 